\title{
Sifat Fisik dan Kecernaan Ransum Sapi Bali yang Mengandung Hijauan Beragam
}

\section{Physical Characteristics and Digestibility of Bali Cattle Fed Containing Various Forage}

\author{
N. N. Suryani ${ }^{1)}$, I. G. Mahardika ${ }^{1)}$, S. Putra ${ }^{1)}$, dan N. Sujaya ${ }^{2)}$ \\ ${ }^{1)}$ Fakultas Peternakan Universitas Udayana, Denpasar - Bali \\ ${ }^{2)}$ Program Studi Ilmu Kesehatan Masyarakat Universitas Udayana, Denpasar, Bali \\ Email : mansuryani@yahoo.com \\ (Diterima: 22 Oktober 2014; Disetujui: 5 Januari 2015)
}

\begin{abstract}
ABSTRAK
Penelitian ini bertujuan untuk mengetahui pengaruh komposisi dan jenis hijauan beragam terhadap sifat fisik dan kecernaan ransum pada sapi Bali. Percobaan menggunakan Rancangan Acak Kelompok (RAK) terdiri dari 4 perlakuan ransum dengan 3 kelompok berat badan sebagai ulangan. Perlakuan ransum disusun berdasarkan bahan kering adalah: (A) rumput gajah $45 \%+$ jerami padi $0 \%+$ gamal $15 \%$ + kaliandra $10 \%+$ konsentrat $30 \%$; (B) rumput gajah $30 \%+$ jerami padi $10 \%+$ gamal $20 \%$ + kaliandra $10 \%+$ konsentrat $30 \%$; (C) rumput gajah $15 \%$ + jerami padi $20 \%$ + gamal $25 \%$ + kaliandra $10 \%$ + konsentrat 30\% dan (D) rumput gajah $0 \%$ + jerami padi $30 \%$ + gamal $30 \%$ + kaliandra $10 \%$ + konsentrat 30\%. Peubah yang diukur adalah sifat fisik dan kecernaan ransum. Data dianalisis menggunakan sidik ragam. Hasil penelitian menunjukkan, sapi Bali yang diberi perlakuan $\mathrm{D}$ memiliki densitas tertinggi $(\mathrm{P}<0,05)$ yaitu $0,313 \mathrm{~g} / \mathrm{ml}, \mathrm{KCBK}$ dan KCPK tertinggi $(\mathrm{P}<0,05)$ masing-masing $67,78 \%$ dan $71,42 \%$ namun KCSK terendah $(\mathrm{P}<0,05)$ yaitu 49,34\%. Berdasarkan hasil penelitian ini dapat disimpulkan bahwa ransum D mampu meningkatkan densitas dan daya serap air serta meningkatkan KCBK dan KCPK ransum.
\end{abstract}

Kata kunci: hijauan beragam, sifat fisik, kecernaan, sapi Bali

\section{ABSTRACT}

This study aimed at determining the effect of providing various forage composition on physical features and rations digestibility of Bali cattle. The method used randomized block design to collect data with 4 treatments and 3 replications. The treatments consisting of ration composition based on DM namely: A $45 \%$ elephant grass $+0 \%$ rice straw $+15 \%$ glyricidia + $10 \%$ calliandra $+30 \%$ concentrate $) ; B(30 \%$ elephant grass $+10 \%$ rice straw $+20 \%$ glyricidia + $10 \%$ calliandra $+30 \%$ concentrate $) ; C(15 \%$ elephant grass $+20 \%$ rice straw $+25 \%$ glyricidia $+10 \%$ calliandra $+30 \%$ concentrate $)$ and D $(0 \%$ elephant grass $+30 \%$ rice straw $+30 \%$ glyricidia $+10 \%$ calliandra $+30 \%$ concentrate). The measured variables were physical features and ration digestibility. Collected data were analyzed by analysis of variance. The result showed that Bali cattle offered ration D performed the highest density $(P<0.05)$ at $0.313 \mathrm{~g} / \mathrm{ml} . \mathrm{D}$ generated the highest DM and CP digestibility $(P<0.05)$, respectively at $67.78 \%$ and $71.42 \%$. But it showed the lowest $C F$ digestibility $(P<0.05)$ at $49.34 \%$. In conclusion, ration $D$ increased the density, water re-gain capacity, DM and CP digestibility of ration.

Keywords: various forage, physical features, digestibility, Bali cattle

\section{PENDAHULUAN}

Pakan ruminansia umumnya terdiri atas hijauan sebagai sumber serat dan supplemen berupa konsentrat maupun leguminosa. Pakan hijauan lokal segar yang umum diberikan kepada ternak menurut Chuzaemi et al. (1997) adalah rumput gajah (Pennisetum purpureum), 
gamal (Gliricidia) dan kaliandra (Calliandra callothyrsus). Rumput gajah berfungsi sebagai sumber energi, gamal dan kaliandra sebagai sumber protein. Gamal merupakan rumen degradable protein (RDP) karena 60,73\% protein gamal terdegradasi dalam rumen dan kaliandra dikategorikan sebagai by-pass protein untuk ternak ruminansia tercermin dari kandungan rumen undegradable protein (RUP) sebesar 25,35\% .

Keterbatasan ketersediaan hijauan segar di musim kemarau, umumnya peternak memberikan pakan pengganti berupa jerami padi. Jerami padi merupakan limbah pertanian yang paling potensial dan terdapat hampir di seluruh daerah di Indonesia. Sebenarnya jerami padi mengandung $80 \%$ nutrien yang dapat dicerna sehingga jerami padi berpotensi sebagai sumber energi bagi ternak (Jackson, 1978). Namun kenyataannya kecernaan jerami padi pada ternak ruminansia hanya mencapai 45-50\%. Rendahnya kecernaan jerami padi disebabkan karena sudah mengalami proses lignifikasi dan silikafikasi serta mengandung nitrogen (N) yang rendah (Van Soest, 2006).

Sebagai pakan ternak, jerami padi bersifat mengembang (bulky) dan mengandung selulose dan hemiselulose yang tinggi. Kandungan Total Digestible Nutrient (TDN) rendah, protein kasar (PK) rendah, kecernaan rendah, dan serat kasar (SK) tinggi (Lamid et al., 2013). Lambatnya fermentasi di dalam rumen dan rendahnya nutrisi yang terkandung dalam jerami padi membatasi pemanfaatannya untuk aktivitas mikroba rumen maupun hewan inang (Yulistiani et al., 2011). Optimalisasi penggunaan jerami padi sebagai pakan ternak perlu diimbangi dengan hijauan lain sebagai sumber protein yang larut di dalam rumen yaitu gamal (Glyricidia). Penambahan gamal pada pakan yang menggunakan jerami padi bertujuan untuk memberikan sumber nitrogen bagi kehidupan mikroorganisme rumen.

Kualitas hijauan di daerah tropis biasanya rendah dan nitrogen umumnya sebagai faktor pembatas utama pada pakan hijauan kualitas rendah (Koster et al., 1996).
Apabila kebutuhan $\mathrm{N}$ terpenuhi, maka pertumbuhan mikroba rumen akan meningkat, demikian juga halnya dengan fermentasi rumen. Akibatnya, karbohidrat struktural terutama selulosa dan hemiselulosa akan difermentasi secara ekstensif (Nolte dan Ferreira, 2005) sehingga kecernaan pakan meningkat.

Kualitas pakan ternak ruminansia sangat ditentukan oleh kecernaannya. Kecernaan pakan berhubungan erat dengan komposisi kimianya dan serat kasar mempunyai pengaruh terbesar terhadap kecernaan. Serat kasar dalam ransum ternak ruminansia sangat penting untuk menjaga kondisi rumen tetap sehat dan menunjang sintesis protein mikroba dengan mempertahankan kondisi rumen yang stabil (Xu et al., 2014).

Kecernaan ransum didefinisikan sebagai bagian ransum yang tidak diekskresikan di dalam feses sehingga diasumsikan bagian tersebut diserap oleh tubuh hewan. Kecernaan dinyatakan dengan dasar bahan kering (McDonald et al., 2002). Sifat fisik tanaman hijauan dapat ditinjau dari sifat keambaan (bulkiness), sifat daya serap air (water regain capacity), maupun sifat kelarutannya dalam air (water solubility). Sifat fisik tersebut erat kaitannya dengan tingkat degradabilitas dan fermentabilitas di dalam rumen (Suhartati et al., 2004). Semakin jelek sifat fisik hijauan, maka semakin rendah kualitasnya karena kecernaannya di dalam rumen rendah.

Suplementasi gamal sampai 25\% dari bahan kering (BK) ransum yang menggunakan 20\% jerami padi mampu meningkatkan kecernaan bahan kering (KCBK) dan kecernaan bahan organik (KCBO) ransum sapi Bali secara in vitro masing-masing 45,97\% dan 46,87\% dibanding ransum tanpa jerami padi dengan suplementasi $15 \%$ gamal menghasilkan KCBK dan KCBO masing-masing 40,67\% dan 41,29\% (Suryani et al., 2013). Penelitian ini bertujuan untuk mengevaluasi pengaruh komposisi dan jenis hijauan beragam terhadap sifat fisik dan kecernaan ransum pada sapi Bali. 


\section{METODE}

Penelitian dilaksanakan selama tiga bulan menggunakan 12 ekor sapi Bali jantan dengan bobot badan 181-265 kg. Rancangan acak kelompok (RAK) yang terdiri dari empat perlakuan ransum dengan tiga kelompok bobot badan sebagai ulangan digunakan untuk menempatkan sapi Bali pada kandang individu. Setiap kandang dilengkapi dengan tempat pakan dan minum.

Ransum yang diberikan berupa ransum komplit dalam bentuk mash terdiri dari $70 \%$ hijauan dan 30\% konsentrat. Komposisi ransum disajikan pada Tabel 1, dan kandungan nutrien ransum pada Tabel 2 . Ransum dan air minum diberikan mulai pukul 08.00 secara ad libitum.

\section{Sifat fisik ransum yang diukur adalah:}

\section{Densitas}

Masing-masing sampel ransum yang telah digiling halus dimasukkan ke dalam tabung silinder ukuran $37 \mathrm{ml}$ sampai permukaan rata dan selanjutnya ditimbang. Densitas dapat dihitung dengan rumus:

$$
\text { Densitas }=\frac{\text { berat sampel }}{\text { volume tabung }}
$$

2. Daya serap air

Sampel ransum yang sudah kering udara (dioven dengan oven $60^{\circ} \mathrm{C}$ ) dan telah digiling halus dimasukkan ke dalam tabung sebanyak 3 gram dan diberi air sebanyak 25 ml. Kemudian sampel tersebut direndam air 1x24 jam. Setelah direndam, sampel disaring dengan kertas saring dan disedot dengan pompa vakum sampai airnya tidak menetes. Selanjutnya sampel ditimbang untuk diperoleh daya serap air dengan rumus:

$$
\text { Daya serap air }=\frac{\text { (berat akhir-berat kertas saring)-berat sampel awal }}{\text { berat sampel awal }} \times 100 \%
$$

Tabel 1. Komposisi ransum dalam bahan kering

\begin{tabular}{lrrrr}
\hline \multirow{2}{*}{ Bahan Penyusun Ransum } & \multicolumn{4}{c}{ Ransum Perlakuan } \\
\cline { 2 - 5 } & A & B & C & D \\
\hline Rumput gajah (\%) & 45,00 & 30,00 & 15,00 & 0,00 \\
Jerami padi (\%) & 0,00 & 10,00 & 20,00 & 30,00 \\
Gamal (\%) & 15,00 & 20,00 & 25,00 & 30,00 \\
Kaliandra (\%) & 10,00 & 10,00 & 10,00 & 10,00 \\
Konsentrat (\%) & 30,00 & 30,00 & 30,00 & 30,00 \\
\hline Total & 100,00 & 100,00 & 100,00 & 100,00 \\
\hline
\end{tabular}

Tabel 2. Kandungan nutrien ransum dalam bahan kering

\begin{tabular}{lrrrr}
\hline \multirow{2}{*}{ Kandungan Nutrien Ransum } & \multicolumn{4}{c}{ Ransum Perlakuan } \\
\cline { 2 - 5 } & A & B & C & D \\
\hline Energi (kkal/kg) & 3346 & 3307 & 3297 & 3109 \\
Protein Kasar (\%) & 11,71 & 11,51 & 11,54 & 12,05 \\
Lemak Kasar (\%) & 1,63 & 1,83 & 1,65 & 2,29 \\
Serat Kasar (\%) & 25,36 & 25,94 & 25,53 & 21,59 \\
TDN (\%) & 60,98 & 59,65 & 58,65 & 60,91 \\
NDF (\%) & 62,57 & 58,23 & 56,23 & 59,40 \\
ADF (\%) & 45,48 & 42,76 & 38,10 & 36,95 \\
ADL (\%) & 3,45 & 4,78 & 5,23 & 7,78 \\
\hline Kenyyyy
\end{tabular}

Keterangan: Analisa dilakukan di Laboratorium Nutrisi Lokal Penelitian Sapi Potong Grati (2011) 
3. Daya larut air

Sampel ransum kering udara (dioven dengan temperatur $60^{\circ} \mathrm{C}$ ) yang telah digiling halus dan disaring dengan diameter saringan 1 mm dimasukkan ke dalam cawan sebanyak 3 gram. Kemudian sampel direndam 1x24 jam. Setelah direndam, sampel disaring dengan kertas saring dan disedot dengan pompa vakum sampai airnya tidak menetes, dilanjutkan dengan pengovenan sampel pada suhu $105^{\circ} \mathrm{C}$ selama 2 jam, kemudian ditimbang.

Daya larut air $=[$ [berat bahan awal $-($ berat bahan kering akhir - berat kertas saring)]/ berat bahan kering awal] x 100\% ]]

\section{Kecernaan Ransum}

Kecernaan ransum diukur melalui periode koleksi total selama 7 hari pada minggu terakhir penelitian. Pengamatan selama koleksi total dilakukan mulai pukul 08.00 WITA sampai 08.00 WITA keesokan harinya. Ransum dan sisa ransum diambil masing-masing $200 \mathrm{~g}$ setiap hari dan pada akhir koleksi total dicampur dan dikomposit sesuai dengan ternaknya. Setelah dicampur, diambil masing-masing $200 \mathrm{~g}$ untuk dilakukan analisa laboratorium. Demikian juga halnya dengan feses. Feses yang dikeluarkan oleh sapi segera ditampung pada bagian belakang kandang sapi dan ditimbang selama 24 jam diketahui. Setelah dikeringkan matahari dan dikomposit di akhir penelitian, feses masingmasing ternak diambil $200 \mathrm{~g}$ untuk analisa laboratorium.
Data yang diperoleh pada penelitian dianalisis dengan sidik ragam. Apabila terdapat hasil yang berbeda nyata $(\mathrm{P}<0,05)$ antar perlakuan, maka dilanjutkan dengan uji kontras ortogonal pada taraf 5\% (Steel dan Torrie, 1991).

\section{HASIL DAN PEMBAHASAN}

\section{Sifat Fisik Ransum}

Sifat fisik bahan penyusun ransum merupakan salah satu indikator untuk mengetahui kualitas bahan. Densitas ransum mengindikasikan keambaan. Semakin rendah densitas suatu pakan, maka makin amba pakan tersebut. Hasil penelitian ini menunjukkan semakin banyak kandungan rumput gajah di dalam ransum (ke arah perlakuan A), maka semakin kecil densitasnya (Tabel 3). Walaupun ransum $\mathrm{C}$ dan $\mathrm{D}$ mengandung lebih banyak jerami padi dibanding perlakuan $\mathrm{A}$ dan $\mathrm{B}$, tetapi karena kandungan gamalnya lebih tinggi, maka densitasnya juga menjadi lebih tinggi. Perlakuan A dan B menunjukkan perbedaan yang nyata $(\mathrm{P}<0,05)$ dengan perlakuan $\mathrm{C}$ dan $\mathrm{D}$.

Berdasarkan daya serap air, semua perlakuan menunjukkan perbedaan yang nyata $(\mathrm{P}<0,05)$. Perlakuan $\mathrm{B}, \mathrm{C}$ dan $\mathrm{D}$ mengandung lebih banyak jerami padi yang diimbangi dengan kandungan gamal yang lebih banyak, maka mempunyai daya serap air yang nyata $(\mathrm{P}<0,05)$ lebih tinggi masing-masing $3,44 \%$; 17,92 dan 28,67\% dibandingkan dengan perlakuan A. Menurut Suhartati et al. (2004), daya serap air yang tinggi akan menyebabkan

Tabel 3. Sifat fisik ransum

\begin{tabular}{|c|c|c|c|c|c|}
\hline \multirow{2}{*}{ Sifat Fisik Ransum } & \multicolumn{4}{|c|}{ Perlakuan } & \multirow{2}{*}{ SEM } \\
\hline & A & B & $\mathrm{C}$ & $\mathrm{D}$ & \\
\hline Densitas (g/ml) & $0,297^{\mathrm{a}}$ & $0,293^{\mathrm{a}}$ & $0,321^{\mathrm{b}}$ & $0,313^{b}$ & 0,0029 \\
\hline Daya Serap Air (\%) & $134,595^{\mathrm{a}}$ & $139,227^{b}$ & $158,717^{\mathrm{c}}$ & $173,183^{\mathrm{d}}$ & 1,0125 \\
\hline Daya Larut Air (\%) & $51,900^{\mathrm{b}}$ & $51,793^{\mathrm{b}}$ & $50,753^{\mathrm{a}}$ & $50,749^{\mathrm{a}}$ & 0,8023 \\
\hline
\end{tabular}

Keterangan :

$\mathrm{A}=$ rumput gajah $45 \%+$ jerami padi $0 \%+$ gamal $15 \%+$ kaliandra $10 \%+$ konsentrat $30 \%$

$\mathrm{B}=$ rumput gajah $30 \%+$ jerami padi $10 \%+$ gamal $20 \%+$ kaliandra $10 \%+$ konsentrat $30 \%$

$\mathrm{C}=$ rumput gajah $15 \%+$ jerami padi $20 \%+$ gamal $25 \%+$ kaliandra $10 \%+$ konsentrat $30 \%$

$\mathrm{D}=$ rumput gajah $0 \%$ + jerami padi $30 \%$ + gamal $30 \%$ + kaliandra $10 \%$ + konsentrat $30 \%$

Superskrip yang berbeda pada baris yang sama adalah berbeda nyata $(\mathrm{P}<0,05)$

$\mathrm{SEM}=$ "Standard Error of the Treatment Means" 
pakan lebih terbuka terhadap serangan bakteri rumen. SeBaliknya, jika daya serap air rendah, pakan tersebut sukar dimasuki bakteri rumen sehingga kecernaan pakan juga menjadi rendah. Daya larut air perlakuan A dan B tidak berbeda $(\mathrm{P}>0,05)$, demikian juga perlakuan $\mathrm{C}$ dan $\mathrm{D}$ tidak berbeda $(\mathrm{P}>0,05)$. Akan tetapi perlakauan $C$ dan $D$ nyata $(P<0,05)$ lebih rendah dibanding perlakuan A.

\section{Kecernaan Ransum}

Kecernaan ransum pada perlakuan D dengan komposisi hijauan $0 \%$ rumput gajah + $30 \%$ jerami padi $+30 \%$ gamal $+10 \%$ kaliandra, nyata meningkatkan KCBK $(\mathrm{P}<0,05)$ dibandingkan perlakuan lainnya (Tabel 4). Hal ini berhubungan dengan sifat fisik ransum khususnya daya serap air yang paling tinggi dari perlakuan $\mathrm{D}$, sehingga memudahkan mikroba rumen mencerna ransum lebih baik. Densitas tertinggi pada ransum $\mathrm{D}$ menunjukkan kemampuan ransum menyediakan nutrien bagi mikroba rumen sehingga meningkatkan aktivitasnya dan kecernaan BK meningkat. Nilai kecernaan merupakan indikator terhadap kemampuan suatu pakan dalam menyediakan kebutuhan nutrien bagi ternak. Koster et al. (1996) menyatakan bahwa penambahan RDP pada level tertentu pada pakan yang mengandung hijauan kualitas rendah, mampu meningkatkan konsumsi BK, BO, kecernaan nutrien maupun sintesis protein mikroba.
Pada sapi yang mendapat perlakuan D, walaupun sumber energi hijauan hanya dari jerami padi yang notabene mempunyai kualitas lebih rendah dibanding rumput gajah, namun dengan adanya 30\% gamal sebagai RDP yang mampu memasok nitrogen bagi mikroba, pada akhirnya menghasilkan KCBK tertinggi. Ketersediaan unsur $\mathrm{N}$ umumnya merupakan faktor pembatas pada ternakternak yang mendapat ransum mengandung hijauan kualitas rendah. Apabila kebutuhan nitrogen terpenuhi, maka pertumbuhan mikroba rumen akan meningkat demikian juga halnya dengan proses fermentasi di dalam rumen. Kondisi ini meningkatkan fermentasi karbohidrat struktural yang berasal dari hijauan untuk menyediakan energi sebagai motor penggerak populasi mikroba rumen. Perbedaan jenis dan komposisi hijauan pada ransum mengakibatkan KCBO juga tertinggi pada sapi yang mendapat perlakuan $\mathrm{D}$, namun secara statistik tidak menunjukkan perbedaan yang nyata.

Kecernaan serat kasar (KCSK), tertinggi pada sapi yang mendapat perlakuan A yaitu 63,34\% (Tabel 4). Pemanfaatan jerami padi dalam ransum menyebabkan penurunan kecernaan serat kasar dan penurunan kecernaan serat kasar ini semakin meningkat dengan semakin banyaknya kandungan jerami padi dalam ransum. Menurunkan porsi rumput gajah dengan meningkatkan jerami padi sebagai sumber energi yang diimbangi dengan

Tabel 4. Koefisien cerna ransum pada sapi Bali

\begin{tabular}{|c|c|c|c|c|c|}
\hline \multirow{2}{*}{ Peubah } & \multicolumn{4}{|c|}{ Ransum Perlakuan } & \multirow{2}{*}{ SEM } \\
\hline & A & $\mathrm{B}$ & $\mathrm{C}$ & $\mathrm{D}$ & \\
\hline KCBK (\%) & $57,25^{\mathrm{a}}$ & $52,39^{\mathrm{a}}$ & $57,30^{\mathrm{a}}$ & $67,78^{b}$ & 1,02 \\
\hline $\mathrm{KCBO}(\%)$ & $72,17^{\mathrm{a}}$ & $70,12^{\mathrm{a}}$ & $71,96^{\mathrm{a}}$ & $72,30^{\mathrm{a}}$ & 0,86 \\
\hline $\operatorname{KCSK}(\%)$ & $63,34^{\mathrm{a}}$ & $61,07^{\mathrm{a}}$ & $54,56^{\mathrm{ab}}$ & $49,34^{b}$ & 1,39 \\
\hline $\mathrm{KCPK}(\%)$ & $66,84^{\mathrm{ab}}$ & $65,26^{\mathrm{b}}$ & $69,75^{\text {ac }}$ & $71,42^{c}$ & 0,51 \\
\hline
\end{tabular}

Keterangan :

$\mathrm{A}=$ rumput gajah $45 \%+$ jerami padi $0 \%+$ gamal $15 \%+$ kaliandra $10 \%+$ konsentrat $30 \%$

$\mathrm{B}=$ rumput gajah $30 \%+$ jerami padi $10 \%+$ gamal $20 \%+$ kaliandra $10 \%+$ konsentrat $30 \%$

$\mathrm{C}=$ rumput gajah $15 \%+$ jerami padi $20 \%+$ gamal $25 \%+$ kaliandra $10 \%+$ konsentrat $30 \%$

$\mathrm{D}=$ rumput gajah $0 \%+$ jerami padi $30 \%+$ gamal $30 \%+$ kaliandra $10 \%+$ konsentrat $30 \%$

Superskrip yang berbeda pada baris yang sama adalah berbeda nyata $(\mathrm{P}<0,05)$

SEM = "Standard Error of the Treatment Means" 
peningkatan gamal sebagai RDP dalam ransum sapi Bali tetap menurunkan KCSK. Peningkatan jerami padi dan menurunnya porsi rumput gajah dalam ransum sebagai sumber energi, meningkatkan ADL ransum (Tabel 2). Kelemahan penggunaan jerami padi sebagai pakan ternak adalah rendahnya koefisien cerna jerami padi karena availabilitas karbohidrat dari serat kasarnya adalah rendah. Hal ini disebabkan karena sudah mengalami proses lignifikasi dan silisifikasi serta mengandung nitrogen yang rendah (Van Soest, 2006).

Menurut Varga dan Kolver (1997), kecernaan serat bukan merupakan nilai yang statis karena merupakan kompetisi antara kecepatan pencernaan itu sendiri dengan laju alir digesta. Laju alir digesta berkorelasi positif dengan konsumsi pakan. Jika konsumsi pakan meningkat, maka laju alir digesta meningkat dan partikel pakan terutama hijauan belum sepenuhnya tercerna sehingga menghasilkan kecernaan serat yang rendah. Namun demikian, tetap terjadi peningkatan konsumsi energi karena proses pencernaan pasca rumen. Empat faktor yang berperan mengatur kecernaan pakan serat pada ternak ruminansia yaitu: 1) struktur dan komposisi hijauan yang memungkinkan akses mikroba rumen mencapai nutrien yang terkandung di dalamnya; 2) populasi mikroba yang dominan mencerna pakan serat; 3) komplek hidrolitik enzim mikroba yang melekat pada pakan dan 4) proses mastikasi, salivasi dan digesta kinetik ternak yang bersangkutan untuk meningkatkan ketersediaan nutrien.

Kecernaan protein kasar $(\mathrm{KCPK})$ pada sapi yang mendapat ransum B secara statistik tidak berbeda $(\mathrm{P}>0,05)$ dibandingkan dengan sapi yang mendapat ransum A. Peningkatan kandungan gamal menjadi 25\% (perlakuan C) dan $30 \%$ (perlakuan D), KCPK cenderung meningkat dan tertinggi pada sapi yang mendapat perlakuan D. Peningkatan KCPK akibat sifat protein gamal yang mudah terdegradasi di dalam rumen, dan peningkatan gamal akan menyediakan ammonia yang lebih banyak bagi mikroba rumen untuk beraktivitas dan meningkatkan populasinya sehingga kecernaan protein menjadi meningkat. Stern et al. (2006) menyatakan kecernaan protein dalam rumen merupakan proses yang kompleks yang dipengaruhi oleh berbagai faktor seperti: kelarutan dan struktur protein, aktivitas mikroba proteolitik, $\mathrm{pH}$ rumen, akses mikroba terhadap protein tersebut dan lama waktu tinggal di dalam rumen. Beberapa penelitian yang telah dilakukan, menunjukkan indikasi kecernaan protein yang menurun dengan menurunnya $\mathrm{pH}$ rumen dan jenis ransum, akan memicu populasi mikroba tertentu yang dominan di dalam rumen. Bach et al. (2005) menambahkan, faktor penting yang berpengaruh terhadap kecernaan protein adalah tipe protein dan interaksinya dengan nutrien lain (khususnya karbohidrat dalam ransum dan dalam rumen) serta populasi mikroba yang dominan (tergantung jenis pakan, laju alir dan $\mathrm{pH}$ rumen). Selanjutnya dikatakan bahwa kecernaan protein tidak hanya melulu akibat kerja enzim proteolitik saja, tetapi juga ada suport dari enzim lainnya. Penambahan enzim amilase dapat meningkatkan kecernaan protein 6-20\%.

\section{KESIMPULAN}

Berdasarkan hasil dan pembahasan di atas, dapat disimpulkan bahwa pemberian ransum dengan komposisi $30 \%$ jerami padi + $30 \%$ gamal $+10 \%$ kaliandra $+30 \%$ konsentrat dari BK ransum, mampu meningkatkan densitas dan daya serap air ransum. Selain itu juga mampu meningkatkan $\mathrm{KCBK}, \mathrm{KCBO}$ dan KCPK akan tetapi menurunkan KCSK ransum.

\section{UCAPAN TERIMA KASIH}

Penulis menyampaikan terima kasih kepada Rektor Universitas Udayana dan Ketua Lembaga Penelitian dan Pengabdian Kepada Masyarakat atas pendanaan, kepada Dekan Fakultas Peternakan atas fasilitas yang disediakan untuk penelitian ini. Kepada Kepala Laboratorium Nutrisi Fakultas Peternakan Universitas Udayana dan semua pihak yang berperan. 


\section{DAFTAR PUSTAKA}

Bach, A., S. Calsamiglia, and M. D. Stern. 2005. Nitrogen metabolism in the rumen. J. Dairy Sci. 88:(E.Suppl.):E9E21. American Dairy Science Association.

Chuzaemi, S., Hermanto, Soebarinoto, dan H. Sudarwati. 1997. Evaluasi protein pakan ruminansia melalui pendekatan sintesis protein mikrobial di dalam rumen: Evaluasi kandungan RDP dan UDP pada beberapa jenis hijauan segar, limbah pertanian dan konsentrat. Jurnal Penelitian Ilmu-Ilmu Hayati (Life Sciences) Vol. 9 No. 1, Juni. 7789.

Jackson, M.G. 1978. Rice straw as livestock feed in ruminant nutrition. Selected articles from the World Anim. Rev. 12 : 34-40.

Koster, H. H., R. C. Cochran, E. C. Titgemeyer, E. S. Vanzant, I. Abdelgadir and G. St-Jean. 1996. Effect of increasing degradable intake protein on intake and digestion of lowquality, tallgrass-prairie forage by beef cows. J. Anim. Sci. 1996. 74:24732481.

Lamid, M., N. N. T. Puspaningsih dan S. Mangkoedihardjo. 2013. Addition of lignocellulolytic enzymes into rice straw improves in vitro rumen fermentation products. $J$ Appl Environ Biol Sci 3(9):166-171.

McDonald, P. R., A. Edwards, J. F. D. Greenhalg dan C. A. Morgan. 2002. Animal Nutrition 6th Edition. Longman Scientific and Technical Co. Published in The United States with John Willey and Sons Inc, New York.

Nolte, J. V. dan A.V. Ferreira. 2005. The effect of rumen degradable protein level and source on the duodenal essential amino acid profile of sheep. J. of Anim. Sci. 35 (3): 162-171.
Steel, R. G. D. Ang J. H. Torrie. 1991. Priciples and Procedures of Statistic. McGraw-Hill Book Co. Inc., New york.

Stern, M. D., A. Bach dan S. Calsamiglia. 2006. New Concepts in Protein Nutrition of Ruminants. 21 $1^{\text {st }}$ Annual Southwest Nutrition \& Management Conference. February 23-24. pp: 4566.

Suhartati, F. M., W. Suryapratama dan S. Rahayu. 2004. Analisis Sifat Fisik Rumput Lokal. Animal Production 6 (1): 37-42.

Suryani, N. N., I. K. M. Budiasa dan I. P. A Astawa. 2013. Suplementasi gamal sebagai rumen degradable protein (RDP) untuk meningkatkan kecernaan (In vitro) ransum ternak ruminansia yang mengandung jerami padi. Majalah ilmiah Peternakan 16 (1): 15.

Varga, G. A. and E. S. Kolver. 1997. Microbial and animal limitations to fiber digestion and utilization. Paper presented as part of the 37th Annual Ruminant Nutrition Conference: New Development in Forage Science Contributing to Enhanced Fiber Utilization by Ruminants. J. Nutr. 127: 819S-823S.

Van Soest, P. J. 2006. Review: rice straw, the role of silica and treatments to improve quality. Anim. Feed Sci. Technol.130:137-171.

Yulistiani, D., Z. A. Jelan, J. B. Liang, and N. Abdullah. 2011. Effect of different supplement on degradation of dry matter and fiber of untreated and urea treated rice straw in the rumen of sheep. J Indonesian Trop Anim Agric 36(4): 252-259.

Xu, J., Yujie Hou, Hongbo Yang, Renhuang Shi, Caixia $\mathrm{Wu}$, Yongjiu Huo, and Guoqi Zhao. 2014. Effects of Forage Sources on Rumen Fermentation 
Characteristics, Performance, and Microbial Protein Synthesis in
Midlactation Cows. Asian Australias. J. Anim. Sci. 27 (5): 667-673. 